University of Nebraska - Lincoln

DigitalCommons@University of Nebraska - Lincoln

Faculty Publications: Department of Teaching, Department of Teaching, Learning and Teacher Learning and Teacher Education

Education

$9-1-2002$

\title{
Four Criteria for Engaging Girls in the Middle Level Classroom
}

Gayle A. Buck

University of Nebraska-Lincoln, gabuck@indiana.edu

Nancy Ehlers

Lincoln Public Schools, Lincoln NE

Follow this and additional works at: https://digitalcommons.unl.edu/teachlearnfacpub

Part of the Teacher Education and Professional Development Commons

Buck, Gayle A. and Ehlers, Nancy, "Four Criteria for Engaging Girls in the Middle Level Classroom" (2002). Faculty Publications: Department of Teaching, Learning and Teacher Education. 23.

https://digitalcommons.unl.edu/teachlearnfacpub/23

This Article is brought to you for free and open access by the Department of Teaching, Learning and Teacher Education at DigitalCommons@University of Nebraska - Lincoln. It has been accepted for inclusion in Faculty Publications: Department of Teaching, Learning and Teacher Education by an authorized administrator of DigitalCommons@University of Nebraska - Lincoln. 


\section{Four Criteria for Engaging Girls in the Middle Level Classroom}

\section{Authenticity, choice, conceptual understanding, and motivation all play a} role in engaging middle level learners. This article shows how these criteria apply to designing lessons for girls.

\section{By Gayle Buck \& Nancy Ehlers}

I did not begin my middle level teaching career with a focus on working with young adolescent girls. However, I was not in that new career very long before finding ways to engage girls in middle level science became a priority of mine. This was the result of my daily experiences in the classroom. The girls in my classes were not failing science, but they were not engaged and they did not seem to be very enthusiastic about what we were studying. I began to explore different ways to engage the girls in my classroom.

This exploration continues today with the help of other middle level teachers that I have found who

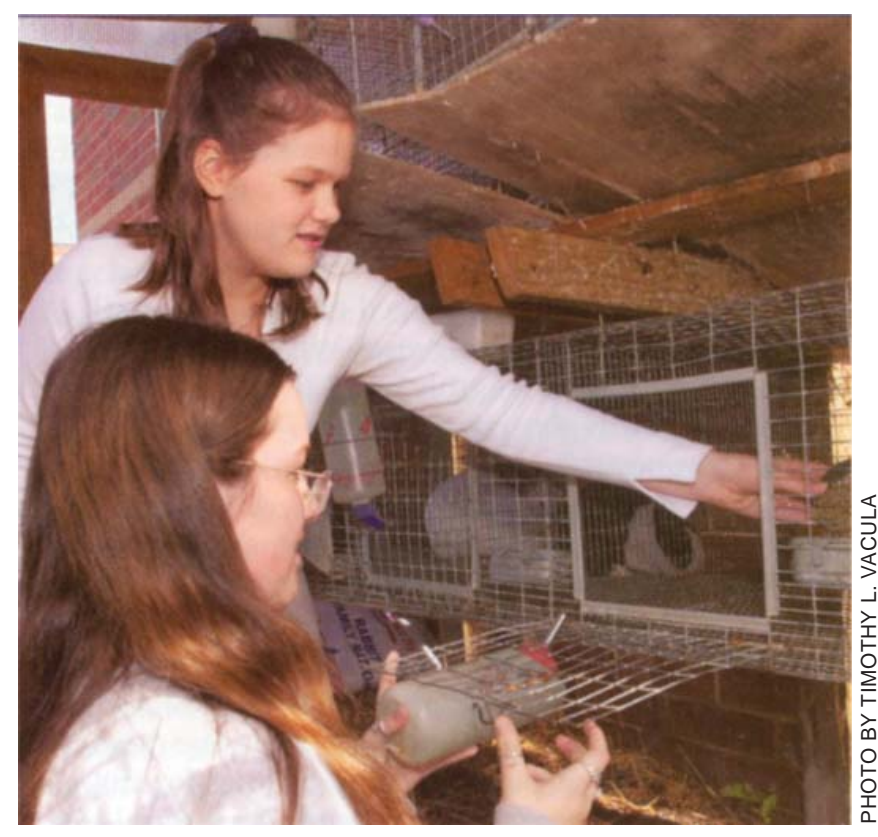

Choice among authentic tasks helps all learners explore their potentials.

share my pursuit. As I explore, my ideas of what it means to be an effective teacher of adolescent girls are changing - with the most profound impact coming from the voices of these young adolescent girls. It is now the wisdom of these girls that is shaping my understanding of what it means to truly include adolescent girls in my middle school projects and programs.

\section{Background}

My early explorations into the various activities, articles, and books focusing on engaging young adolescent girls in the middle school classroom, specifically in the 
science classroom, became overwhelming. I found a lot of information, but the proposed "solutions" were often drastically different from each other-it was hard to know which solutions to pursue.

Some of the advice I was getting as a result of my search focused on what the girls in my classroom were lacking: those experiences, skills, and attitudes that boys tended to bring but girls did not. Jovanovic and King (1998) responded to this when they developed a program to address the fact that adolescent girls lack the exposure to sciencerelated activities outside of school. Like them, I also developed plans to address the "disparities between boys’ and girls' experiences” (Jovanovic \& King, 1998, p. 478). For example, as I was preparing my unit on macroinvertabrates, I took into account the fact that the girls in my classes did not have as much experience as the boys did with handling such creatures prior to coming to my science class. I took this into account as I planned the unit and I included an opportunity to address this "lack of" experience. I took the students to a local stream and had the girls work together to explore and handle the macroinvertebrates we found in the stream. They were then able to use this background experience once we were back in the classroom.

In addition, on the advice of other authors and researchers, I also questioned and explored my own biased teaching practices. The articles I read pointed out that boys receive more attention from teachers, are called upon more frequently, and receive more feedback on their efforts (Jones \& Wheatley, 1990; Sadker \& Sadker, 1994; Tobin, Kahle, \& Fraser, 1990). I, like many other middle level science teachers (Subrahmanyan \& Bozonie, 1996), began to question whether I was giving girls equal treatment. I began to monitor and adjust my own practices; such as consciously calling on the girls the same number of times that I called on the boys, giving the same amount and type of praise to boys and girls, and paying attention to the girls as often as the boys.

It was my reading of In a Different Voice (Gilligan, 1993) that first prompted me to question all of the efforts I had been using for the purpose of engaging the girls in the middle level classroom. In this book, Gilligan explored how girls' voices differ from what we have come to know as adolescent development-an understanding constructed around the development of adolescent boys. Gilligan had me questioning whether it was a "different" understanding of the world that my girls were bringing to the classroom instead of a "lack" of understanding. After I read Gilligan, I read Whose knowledge? Whose science? (Harding, 1991). This book caused me to question whether science,

\section{I started to listen to the girls in my} classroom-I mean really listen. I got particularly tuned-in to the groans and lack of responses from the girls.

or in my case science education, is an inherently "good” discipline or was my understanding of science education lacking? Were my ideas of a good science classroom and curriculum based on the type of classroom that addressed mainly boys' needs and perspectives? These new questions, spurred by these books and several others, took my explorations in a different direction. Specifically, I began to listen to the girls in my classrooms-looking for that "different voice" and an understanding of how a different voice should affect my understanding of being a middle level educator.

I started to listen to the girls in my classroom-I mean really listen. I got particularly tuned in to the groans or the lack of responses from the girls. When did they become engaged? What did I say that caught their attention? When did I lose their attention? I also naturally started to tune into when the girls in my class would become actively involved in the activities. What I was hearing had me begin to question my own teaching in a way that I had not done up to this point.

I continue to listen today. However, I am now able to hear the voices of adolescent girls from across the country. With the help of other National Middle School Association teachers that share in my pursuit to better understand what it means to meet the needs of adolescent girls in the middle level classroom, I have "heard" the voices of 58 young adolescent girls from across six different states. These girls participated in focus group discussions and shared their own feelings and the experiences that they have had in science classrooms. Their discussions were recorded and sent to me for further analysis. What I have heard, is 
continually re-focusing what I believe about being a quality middle level educator.

In order to apply this developing understanding to the classroom, I have used these 58 voices to develop criteria for evaluating the activities and teaching strategies that I incorporate into the projects that I do-projects that are developed to engage adolescent girls in the middle level classroom.

\section{Criteria Established in Response to the Voices of Adolescent Girls}

Along with clarifying these criteria, I will apply each of them to an actual classroom activity. Each criterion will be introduced and used to evaluate the activity. This will demonstrate the procedure used in selecting and modifying projects and lessons for the programs designed to engage adolescent girls in middle level science education. This methodology can be used to evaluate and analyze any activities or lessons. It is a process that will highlight the strengths and

Figure 1

\section{Student Toxicologists Investigate Product Safety}

Learning Episode Summary:

In this learning episode, students become toxicologists that are responsible for developing product safety testing procedures. The objectives are for the students to explore the process of product safety testing, to investigate both scientific and non-scientific factors that influence decisions about product safety, and to develop their own rationale, as consumers, for making decisions about product safety.

In this activity, students select an everyday household product that they use. They develop their own set of research questions that needs to be tested to convince them that their product is "safe." Students then begin researching the testing procedures for their product via the internet, library research, interviews with toxicologists, or possibly even contacting the company. As students proceed they learn how toxicologists use a variety of information to develop their procedures, and how other non-scientific factors may play into a safety decision. Issues such as animal testing, human trials, the role of money and advertising in product safety are a part of this inquiry. Students then evaluate their product on the basis of safety and present product information in some way that is beneficial and informative to their peers (i.e., commercial, research report, news story, pamphlet, etc.)
Figure 2

\section{Authenticity for Student Toxicologists}

Learning Episode Review:

This activity has the students investigate "real" products. These are products that they are familiar with and may use everyday. The process of the product testing, and the role of a toxicologist, is also authentically represented. This activity presents students with other factors, such as animal testing and advertising that may also factor in to "scientific" decisions about product safety.

\section{Evaluation:}

This activity has strong relevance in the lives of these girls and was actually developed as a result of my own students' questions about how safe things like lotions, soaps, and makeup really are and the effects that these chemicals have on the health of people. This learning experience does center on an "authentic" science topic.

weaknesses of a particular activity and help teachers adjust and modify these activities to make them more effective and engaging according to the standards created from conversations with these adolescent girls. The sample learning activity is previewed in Figure 1.

\section{Authentic science}

The girls that I listened to through the use of taped interviews expressed a desire to truly understand science as it relates to the world around them. Overall, the girls did not understand why middle level science education did not allow for an understanding of the science that was a part of their world. The girls would wonder, "Didn't they find another planet or something/' "a way to cure cancer/' and about the "smoke coming out of those pipes.” The list of questions that came out over the course of their discussions was extensive. However, the girls revealed that they seldom found answers to such questions in their science classroom. Instead, they were "learning about those elements-how boring,” or “O.K., that's a chalkboard, it's made out of iron ... their letters are F and E and-Who's going to actually do that?” The girls were able to see themselves fitting into the world of science. But, they claimed that they were seldom able to explore that "fit" in the structure of their middle level science classrooms.

By allowing me to listen in on their group discussion, these girls revealed that in order to engage them in the science lesson, I needed to help them understand their world and themselves (see Figure 2). 


\section{Choice}

The girls told me that they had very diverse, and sometimes contradictory, interests in science. Some girls wanted to dissect something while others found it "really gross" or "bloody." One girl liked learning about Earth Science, "I liked learning about the "big bang’ and how everything got formed.” Another girl found Earth Science really boring.

The girls were not surprised that they liked to study different things, and they did not struggle about whether one should have to learn about fungus or not. They reasoned, “It's like elephants are boring, because I don't like them ... but someone else did elephants and they liked them." The girls did not hesitate to declare that there are different interests and needs, and that everyone should have some choice in what they study.

These girls told me that in order to engage them in science lessons, I should allow for a high degree of choice. Giving students a voice in their own learning by implementing some degree of choice has been supported in other adolescent case studies and focus group research as well as in articles about effective pedagogy (Holland, 2000; Muir, 2000) (see Figure 5).

\section{Pedagogy for understanding}

The girls told me that they wanted to truly understand the science concepts. The girls often mentioned hands-on activities and experiments; however, it was not about what is "fun" for them, but about teaching strategies that provided them with the most understanding. They responded that "I probably need more hands-on stuff because it's kind of confusing when I don't understand stuff. ... Maybe not as much reading and taking notes as actually seeing something, talking about it, or seeing how it actually works." The girls also stressed the need to have the teacher help them understand the concepts that the activity centered around. "Yeah, and if the teacher explains it to you, cause sometimes it'll be like 'O.K., you need to do this experiment,' and you won't know what the experiment is about because they haven't explained anything."

Through their group discussions, the adolescent girls told me that in order to engage them in science lessons and projects, I should develop them in such a way that a deep understanding of the concept is fostered (see Figure 4).
Figure 3

\section{Choice for Student Toxicologists}

Learning Episode Review:

In this activity students are allowed to choose any product that is of particular interest to them. In addition they also have choice in how they will express what they have learned about their own product's safety-a commercial, a research report, a news story, or a pamphlet.

Evaluation:

This activity was actually modified from an existing one in order provide students with a high degree of choice and to lend itself to meeting a more personalized view of the role of science in these girls' lives.

\section{Motivation}

The girls did express a desire to have learning be more "fun" or "interesting." They often used words such as "hate," "fun," and "like" in describing how they did or did not become involved in the daily classroom activities. Comments such as, "I hate reports," "I don't like computers." "I used to hate ... to bring in articles about current events," or "Experiments are fun" were used.

The middle level girls told me that the daily classroom activities associated with the project should be structured in such a way that they are motivated to take part (see Figure 5).

Figure 4

\section{Student Toxicologists Develop Conceptual Understanding}

Learning Episode Review:

The activity has the students become toxicologists. In this role, they design their own product testing procedures as well as researching real product testing procedures. This activity also combines individual research and reflection with group discussion of a variety of real issues, leading the way for connections between the activity and the concept.

\section{Evaluation: ,}

The activity uses authentic pedagogy such that they are active participants in their own learning and creators of their own knowledge. The students are mentally engaged and are required to use higher order thinking skills. The activity is developed in such a way that a deep understanding of the concept is fostered. The activity emphasizes the conceptual understanding that needs to be fostered. 
Figure 5

Student Toxicologists Motivated by Relevance

Learning Episode Review:

The activity conveys an understanding of the concept with issues that are very relevant to the questions and concerns of many adolescents.

\section{Evaluation:}

Because of the high degree of relevance of this topic, students would be motivated to take part in the learning process.

\section{Summary}

These four criteria for engaging female students in science are based on views expressed by middle level girls themselves. These criteria are authentic science, choice, pedagogy for understanding, and motivation. A rubric to help assess engaging lessons is provided in Figure 6.1 use this rubric to evaluate the activities and lessons chosen for projects and programs assigned to adolescent girls. The rubric is not used to assess student performance, but instead to analyze the strengths and weaknesses of the activities in order to select and adjust them. The sample activity that was described in this article was modified from an existing one to incorporate a high degree of choice, which it was initially lacking, to make it more relevant for students. Thus, this activity as it currently exists, illustrates the desired criteria in all areas. It is this process of applying what we have learned from our girls that will help us better meet their needs in the science classroom.

Figure 6

Rubric for Designing Engaging Lessons

\begin{tabular}{|c|c|c|c|c|}
\hline Criteria & High Correlation & Medium Correlation & Low Correlation & No Correlation \\
\hline Authenticity & $\begin{array}{l}\text { The activity directly } \\
\text { responds to questions } \\
\text { adolescent girls have } \\
\text { about their world. }\end{array}$ & $\begin{array}{l}\text { The activity has a } \\
\text { connection (although } \\
\text { not direct) to the } \\
\text { questions adolescent } \\
\text { girls have about their } \\
\text { world. }\end{array}$ & $\begin{array}{l}\text { The activity only has } \\
\text { an indirect connection } \\
\text { to the questions } \\
\text { adolescent girls have } \\
\text { about their world. }\end{array}$ & $\begin{array}{l}\text { The activity has no } \\
\text { connection to the } \\
\text { questions adolescent } \\
\text { girls have about their } \\
\text { world. }\end{array}$ \\
\hline Choice & $\begin{array}{l}\text { The activity does allow } \\
\text { for a high degree of } \\
\text { choice that focuses on } \\
\text { related special interests } \\
\text { of the girls. }\end{array}$ & $\begin{array}{l}\text { The activity allows for } \\
\text { a degree of choice } \\
\text { that focuses on related } \\
\text { special interests of the } \\
\text { girls. } \\
\text { or } \\
\text { The learning episode } \\
\text { leaves room for the } \\
\text { teacher to easily add } \\
\text { choice activities. }\end{array}$ & $\begin{array}{l}\text { The activity does } \\
\text { not allow for choice, } \\
\text { although girls could } \\
\text { request an alternative } \\
\text { assignment if they } \\
\text { choose. }\end{array}$ & $\begin{array}{l}\text { The activity does not } \\
\text { allow for choice. }\end{array}$ \\
\hline $\begin{array}{l}\text { Pedagogy for } \\
\text { Understanding }\end{array}$ & $\begin{array}{l}\text { The activity is } \\
\text { developed in such a } \\
\text { way that a deep under- } \\
\text { standing of the concept } \\
\text { is fostered. }\end{array}$ & $\begin{array}{l}\text { The learning episode } \\
\text { is developed in } \\
\text { such a way that an } \\
\text { understanding of the } \\
\text { concept is fostered. }\end{array}$ & $\begin{array}{l}\text { The activity is devel- } \\
\text { oped in such a way that } \\
\text { those girls who learn in } \\
\text { the traditional manner } \\
\text { can understand. }\end{array}$ & $\begin{array}{l}\text { The activity does } \\
\text { not support a deep } \\
\text { understanding of a } \\
\text { concept. }\end{array}$ \\
\hline Motivation & $\begin{array}{l}\text { The activity is fun and } \\
\text { exciting to adolescent } \\
\text { girls. }\end{array}$ & $\begin{array}{l}\text { The activity involves } \\
\text { some projects that will } \\
\text { interest adolescent } \\
\text { girls. }\end{array}$ & $\begin{array}{l}\text { The activity may create } \\
\text { a new interest for some } \\
\text { adolescent girls. }\end{array}$ & $\begin{array}{l}\text { The activity would not } \\
\text { appeal to the interests } \\
\text { of adolescent girls. }\end{array}$ \\
\hline
\end{tabular}




\section{Conclusion}

Listening to young adolescent girls has greatly altered my ideas of what it means to teach at the middle level. Using the ideas and attitudes that these girls bring with them to the science classroom, I now select what happens in that classroom. Others are encouraged to use this rubric to select activities as they attempt to engage the adolescent girls in the middle level curriculum.

No longer looking upon girls to see what they were lacking, I now look upon them to see what they have. I believe this new understanding has created an atmosphere that further supports the education of adolescent girls. I encourage other teachers to "listen" to the adolescent girls and learn from them.

\section{References}

Gilligan, C. (1993). In a different voice: Psychological theory and women's development. Cambridge, MA: Harvard University Press.

Harding, S. (1991). Whose science? Whose knowledge? Ithaca, NY: Cornell University Press.

Holland, H. (2000). Reaching all learners: You've got to know them to show them. Middle Ground, 3(5), 10-12.

Jovanovic, J., \& King, S. (1998). Boys and girls in the performance-based science classroom: Who's doing the performing? American Educational Research Journal, 35(3), 477-496.
Jones, XL, \& Wheatley, J. (1990). Gender difference in teacher-student interactions in science classrooms. Journal of Research in Science Teaching, 27, 861-874.

Muir, M. (2000). Motivating adolescents: Play to their strengths. Middle Ground, 3(5), 15-16.

Sadker, M., \& Sadker, D. (1994). Failing at fairness: How America's schools cheat girls. New York: Scribners.

Subrahmanyan, L, \& Bozonie, H. (1996). Gender equity in middle school science teaching: Being "equitable" should be the goal. Middle School Journal, 27(5), 3-10.

Tobin, K., Kahle, J., \& Fraser, B. (1990). Window into science classrooms: Problems associated with higher-level cognitive learning. New York: Falmer.

Gayle Buck is an assistant professor in the School of Education at the University of Nebraska, Lincoln. E-mail: gbuck@unlnotes.unl. $\underline{\text { edu }}$

Nancy Ehlers is a middle level science teacher in the Lincoln Public Schools, Nebraska. 